\title{
PRODUCTION OF A BACTERIOCINE-LIKE SUBSTANCE BY GROUP-A STREPTOCOCCI OF M-TYPE 4 AND T-PATTERN 4
}

\author{
Diana W. Johnson, J. R. TAGg and L. W. WannamakeR* \\ Department of Microbiology, University of Otago, Dunedin, New Zealand, \\ and ${ }^{*}$ Departments of Pediatrics and Microbiology, University of \\ Minnesota Medical School, Minneapolis, Minn., USA
}

IN THE COURSE of screening strains of $\beta$-haemolytic streptococci for the production of bacteriocines or bacteriocine-like substances, we observed that all group-A streptococci identified serologically as M-type 4, T-pattern 4 (M4T4) had a similar and characteristic spectrum of activity against a set of indicator organisms (Tagg and Bannister, 1979). This paper describes investigations of this association between antigenic composition and a unique pattern of inhibitory activity, and of the characters of a bacteriocine-like inhibitor produced by strain 20006, an M4T4 group-A streptococcus. This specific inhibitor will be referred to subsequently as "the inhibitor", though evidence was obtained in the course of the study that it was not the only bacteriocine-like substance formed by M4T4 group-A streptococci.

\section{MATERIALS AND METHODS}

Bacterial strains. The following group-A streptococcal strains, from the Department of Pediatrics at Minneapolis, were used: inhibitor-producing M4T4 strains 20006 (Cleary, Johnson and Wannamaker, 1975), 5004 (Malke, 1973), and 71-679, 73-209, 74-196, 74-217, 74-216 and 74-212; inhibitor-producing, M-untypable T-pattern-4 strains 72-454, 72-479 and 74-497; inhibitor non-producing, T-pattern-4 strains with other $M$ antigens 71-694 (M-type 24), 71-696 (M-type 26), 71-699 (M-type 29), 71 -713 (M-type 46), 71-715 (M-type 48), 71-723 (M-type 56), 71-727 (M-type 60), 72-453 (M-type 63) and 74-793 (M-type 22); and an inhibitor non-producing M-type 4, T-pattern-8/25/I-19 strain 74-814. Other inhibitor-producing M4T4 group-A streptococcal strains isolated in the Dunedin Public Hospital were strains T-28, 0794, 3200 and 4916. An inhibitor-producing group-C streptococcal strain, 4003 (M negative, T-pattern 2) was obtained from an equine infection. Variants of group-A strain 20006 that had lost the ability to cause inhibition were obtained from aged Todd-Hewitt broth (THB) cultures as described by Tagg and Wannamaker (1976). Those used in the present study were numbered T-227, T-228, T-232, T-234, T-235, T-236, T-240, T-241, T-250, T-255 and T-256.

The set of standard indicator strains used to detect inhibitor production (table $I$ ) was the same as that used for the "fingerprinting" of streptoccoccal strains (Tagg and Bannister, 1979). One of these indicators, the Staphylococcus epidermidis strain T-18, was used in assays of the inhibitor specifically associated with M4T4 strains. Two group-A streptococcal strains, PF-1643 (M-type 57; see Tagg et al., 1973a) and 71-702 (M-type 32) were used in tests of the mode of action of this inhibitor. Representative bacteria of various other species selected for use in testing the activity spectrum of the M4T4 inhibitor were obtained from the culture collection of the Department of Microbiology, University of Otago. 
Strains were stored at $-70^{\circ} \mathrm{C}$ in skim milk, and subcultured fortnightly on blood agar when in regular use.

TABLE I

Standard indicator strains for bacteriocine-like inhibitors from $\beta$-haemolytic streptococci

\begin{tabular}{ll}
\hline Indicator & \multicolumn{1}{c}{ Strain specification } \\
\hline I1 & Staphylococcus epidermidis, strain T-18 \\
I2 & Group-A streptococcus, strain FF22, M-type 52, T-pattern 3/13 \\
I3 & Group-F streptococcus, strain T-29 \\
I4 & Group-E streptococcus, strain T-6 \\
I5 & Group A streptococcus, strain 71-679, M-type 4, T-pattern 4 \\
I6 & Group-N streptococcus, strain T-21 \\
I7 & Group-A streptococcus, strain 71-698, M-type 28 \\
I8 & Group-A streptococcus, strain W-1, T-pattern 6 \\
I9 & Group-C streptococcus, strain T-148 \\
\hline
\end{tabular}

Culture media. Liquid media tested as substrates for inhibitor production were: Tryptic Soy Broth (TSB; Difco Laboratories, Detroit, Mich., USA); Brain Heart Infusion (Difco); THB (Difco); THB (Pfizer Inc., New York, NY, USA); Difco THB supplemented with $1 \%$ (w/v) Difco Neopeptone, Difco Yeast Extract, or D-glucose (AnalaR, BDH Chemicals, Poole, Dorset); and Difco THB buffered with 0.5M TES\{N-tris (hydroxymethyl) methyl-2-aminoethane sulphonic acid; Sigma Chemicals Co., St Louis, Mo, USA 3 at $p \mathrm{H} \mathrm{7.0.}$

Human blood agar was prepared from Columbia Blood Agar Base (Difco) supplemented with $c .8 \%(\mathrm{v} / \mathrm{v})$ of human blood. The plates were made as an overlay on saline agar $(\mathrm{NaCl} 0.85 \%$ $\mathrm{w} / \mathrm{v}$ and agar $1.5 \% \mathrm{w} / \mathrm{v}$ in distilled water). Sheep-blood agar was prepared similarly with blood obtained from Lab. Services, Auckland, NZ. Chocolate agar was prepared by adding of human blood c. 8\% (v/v) to molten Columbia Blood Agar Base and steaming this for 10-20 min. Columbia Blood Agar Base without added blood was also used. Media used for propagating and testing the action of bacteriophage A25 against various organisms were No. 1 broth and N6 medium (Tagg, Skjold and Wannamaker, 1976b).

Chemicals. Trypsin 1:250 was obtained from Difco, and catalase, protease (Type V), lipase (Types I and VII), $\alpha$-1,4-glucan 4-glucanohydrolase (amylase), hyaluronidase (Type I) and mitomycin $\mathrm{C}$ from Sigma Chemicals.

Sephadex G-100 (Pharmacia, Uppsala, Sweden) was equilibrated in 0.005 $\mathrm{M}$ phosphate buffer at $p \mathrm{H} 6 \cdot 0$. Standard proteins used to calibrate the column were glucagon, myoglobin and cytochrome C (all from Sigma Chemicals). Blue dextran (Pharmacia) was used to determine the void volume of the column.

Acrylamide and $\mathbf{N}, \mathrm{N}^{\prime}$-methylenebisacrylamide for polyacrylamide gels were supplied by Fluka A.G., Buchs S.G., Switzerland. TRIS (hydroxymethyl) amino-methane and sodium dodecyl sulphate (SDS) were obtained from BDH Chemicals, glycine from BDH, N,N, $\mathbf{N}^{\prime}$, $\mathrm{N}^{\prime \prime}$-tetramethylethylenediamine from Sigma, and 2-mercaptoethanol from Koch-Light Laboratories, Colnbrook, England.

Detection of streptococcal products other than inhibitors. Streptococci were screened for the presence of $M$ protein hy the double diffusion technique of Ouchterlony (1949) and for opacity factor (OF) by the slide method of Maxted et al. (1973); fractions from Sephadex G-100 columns were tested similarly.

Amylase activity was detected by examination of the agar around stab cultures in Columbia Blood Agar Base. If amylase was present, the cloudiness of the agar, due to starch grains, was markedly absent in a radius of $c .5 \mathrm{~mm}$ around each stab. This was confirmed by pouring iodine over the surface of the plate (Lee, 1976). The hydrolysis of starch grains was more readily detected in this medium than in other starch-containing media such as Mueller-Hinton medium, (Lee, 1976), Blood Agar Base (BBL, B-D Laboratories Inc., Baltimore, Md, USA), or Nutrient Agar (Difco) supplemented with $1 \%$ (w/v) starch (BBL). The production of DNAase was demonstrated by the use of stab cultures in DNase Test Agar (BBL). Proteinase production was 
demonstrated by the hydrolysis of either casein or gelatin. Skim milk agar was prepared with $1 \%$ (w/v) Skim Milk (BBL), supplemented with Proteose Peptone No. 2 (Difco) $1 \%$ (w/v), Bacto-dextrose (Difco) $0.2 \%(\mathrm{w} / \mathrm{v})$ and agar $2 \%(\mathrm{w} / \mathrm{v})$. Stab cultures were grown overnight at $37^{\circ} \mathrm{C}$ and, if elaborating proteinase, produced a zone of clearance around the stab. The hydrolysis of gelatin was demonstrated by growing stab cultures at $37^{\circ} \mathrm{C}$ closely adjacent to exposed, developed Ilford FP4 film (Ilford Ltd, England) which had been embedded in Columbia Blood Agar Base supplemented with yeast extract 1\%(w/v). Production of proteinase was indicated by the formation of an area of clearing on the film near the stab. Production of hyaluronidase was detected by the use of a capsulated group-A streptococcal strain 71698 (M-type 28). This strain was sensitive to the presence of hyaluronidase when used as indicator in deferred-antagonism tests. After incubation for 18-24 h, non-mucoid growth appeared across the centre of deferred-antagonism streaks when the "producer" organism had released hyaluronidase. A similar effect was reported by Murray and Pearce (1949). Haemolysis was recorded as $\alpha$ or $\beta$ after incubation of stab cultures in blood agar for $18-24 \mathrm{~h}$ at $37^{\circ} \mathrm{C}$. Starch accumulation was demonstrated by a modification of Crowley's method (1959). Gradient plates were prepared with Difco Nutrient Agar $+\mathrm{NaCl} 0.85 \%(\mathrm{w} / \mathrm{v})$, supplemented alternatively with human blood $8 \%(\mathrm{v} / \mathrm{v})$ and maltose $0.8 \%(\mathrm{w} / \mathrm{v})$. Incubation of streak cultures along the gradient was for $48 \mathrm{~h}$ at $37^{\circ} \mathrm{C}$. The presence of starch was shown by spraying the surface of the plates with iodine.

Detection of inhibitory activity. The deferred-antagonism method of Tagg, Read and McGiven (1973b) was used to detect inhibitory activity in solid media, except that incubation was carried out at $30^{\circ} \mathrm{C}$. Inhibition of indicators was recorded as + and its absence as - .

Inhibitory activity in cell-free extracts was detected by a modification of the method of Tagg and McGiven (1971). The whole surface of a plate of Columbia Blood Agar Base was seeded with $0.1 \mathrm{ml}$ of an overnight $\left(30^{\circ} \mathrm{C}\right) \mathrm{THB}$ culture of the indicator strain (Staphylococcus epidermidis strain T-18); 5-mm-diameter wells were cut in the agar. For titration, the volume of the agar in the plate was kept constant at $35 \mathrm{ml}$, the sample volume was $0.1 \mathrm{ml}$ per well, and plates were incubated at $30^{\circ} \mathrm{C}$. When these factors were kept constant, inhibitory activity could be measured by a modification of the critical-dilution method of Mayr-Harting, Hedges and Berkeley (1972), but in the present study the size of the zone of inhibition resulting from diffusion of an undiluted sample was compared with the sizes of zones given by a reference set of dilutions, and the titre inferred from this. Standard titration sets of known inhibitory titres were prepared for use with each new batch of plates and for each fresh indicator culture to ensure that test conditions remained constant. The titres of the standard set were taken as the highest dilution that gave complete inhibition of the lawn of the indicator strain, and was expressed as an equivalent number of arbitrary units (AU) per ml.

Conditions for inhibitor production. The amount of inhibitor produced in various liquid media was compared by growing the producer strain in them at $30^{\circ} \mathrm{C}$ for $18-24 \mathrm{~h}$, heating the culture in a boiling water bath for 10 min., centrifuging it, and testing the supernate.

Inhibitory activity was expressed as the number of AU per mg dry weight of cells. The rate of inhibitor production in THB at $30^{\circ} \mathrm{C}$ was estimated by sampling and measuring the inhibitory activity at intervals; surface-viable counts were also made, and the results expressed as colonyforming units $/ \mathrm{ml}$.

The inducibility of inhibitor production was tested with mitomycin $\mathrm{C}$ at final concentrations of $0.25,0.5$ and $1.0 \mu \mathrm{g} / \mathrm{ml}$ by the method of Jetten, Vogels and deWindt (1972). Induction by ultraviolet light was tested for by streaking a $1-\mathrm{cm}$-wide diametric inoculum on blood agar and irradiating sections for different lengths of time; $45-60 \mathrm{sec}$. gave a $90 \%$ kill. Each section of the streak was then tested for inhibitory activity by cross-streaking the indicator strain as in deferred-antagonism tests.

Extraction of cell-associated inhibitor was attempted by methods described by Tagg and Wannamaker (1978), for the most part with cells boiled at $100^{\circ} \mathrm{C}$ for $10 \mathrm{~min}$., but also with washed cells from THB cultures resuspended in uninoculated THB and boiled for $10 \mathrm{~min}$.

Purification of the inhibitor. The methods used were based upon those outlined by Tagg $\mathrm{et}$ al. (1973a) for the purification of streptococcin A-FF22. Three litres of THB were inoculated and incubated at $25^{\circ} \mathrm{C}$ for 2 days and then heated in a boiling water bath for $30-40 \mathrm{~min}$. to kill the 
cells, extract cell-bound inhibitor and inactivate heat-sensitive streptococcal enzymes. After removal of cell debris by filtration through Celite 545 (Johns-Manville Products, USA) the supernate was cooled and ammonium sulphate added slowly to $80 \%$ saturation. After $18-24 \mathrm{~h}$ at $4^{\circ} \mathrm{C}$, the precipitated proteins were collected by filtration. These were redissolved in a minimal volume, usually $30-40 \mathrm{ml}$, of $0.005 \mathrm{M}$ phosphate buffer at $p \mathrm{H6} .5$. This "crude" extract was desalted and fractionated by gel filtration on Sephadex G-100 to give a "partially purified" inhibitor preparation. The total protein present at each stage of purification was estimated by the method of Lowry et al. (1951), with bovine serum albumin as standard.

Mode of action of the inhibitor. The inhibitor was tested for specificity of adsorption to sensitive and insensitive cells by the method of Dajani and Wannamaker (1973). The procedures described by Dajani and Wannamaker (1973) were used to determine whether the inhibitor was bactericidal or bacteristatic in its action against Staph.epidermidis strain T-18 and group-A streptococcal strain PF-1643.

Inhibitor-containing extracts were obtained from strain 20006. Extracts from strain T-250, an inhibitor-negative derivative of strain 20006 were used as negative controls. The effect of "crude" inhibitor preparations on M4T4 producer strains and on their inhibitor-negative derivatives was tested by the well method (see above).

The possible neutralising action of type- $4 \mathrm{M}$ antiserum on the inhibitor was tested by mixing dilutions of the inhibitor with the antiserum and incubating at $37^{\circ} \mathrm{C}$ for $90 \mathrm{~min}$. The mixtures were titrated for residual inhibitory activity by the well method.

Physicochemical properties of the inhibitor: The effect of $p \mathrm{H}$ on the activity of the inhibitor was tested by adjusting portions of crude extract within the $p \mathrm{H}$ range of 2-12. Control extracts were diluted by an equivalent amount with distilled water. After boiling the samples for $15 \mathrm{~min}$., the $p \mathrm{H}$ was readjusted to 6.5-7.0 and each tube adjusted to the same final volume before assaying for inhibitory activity.

The sensitivity of the crude inhibitor to trypsin, protease, lipase, amylase and catalase was tested by a modification of the method of Dajani and Wannamaker (1969). A final enzyme concentration of $2.5 \mathrm{mg} / \mathrm{ml}$ was used $\left(0.75 \mathrm{mg} / \mathrm{ml}\right.$ for catalase); incubation was at $37^{\circ} \mathrm{C}$ for $3 \mathrm{~h}$ at $p \mathrm{H} 7 \cdot 5$. The enzymes were inactivated by boiling for $5 \mathrm{~min}$. and the treated preparations compared for activity with a control untreated extract.

Fractionation on Sephadex G-100 (Tagg et al., 1973a) gave an estimate of the m.w. of the inhibitor. Another determination of them.w. was obtained by the use of SDS-polyacrylamide-gel electrophoresis(Laemmli, 1970). Gels of $10 \%$ polyacrylamide were prepared and run for $3 \frac{1}{2} \mathrm{~h}$ at 7 $\mathrm{mA} / \mathrm{gel}$; the electrode buffer and gel buffer were adjusted to $p \mathrm{H} \mathrm{7.5}$, the sample buffer to $p \mathrm{H} 6 \cdot 5$.

Gels were stained for protein with Coomassie Brilliant Blue $1 \%(\mathrm{w} / \mathrm{v})$ in a 5:1:5 mixture of methanol:glacial acetic acid: water. Similar gels were embedded in agar seeded with indicator inoculum to detect the inhibitor (Jetten et al., 1972). Sufficient non-specifically toxic SDS was removed from the gels by soaking them for $5 \mathrm{~h}$ in $0.01 \mathrm{M} \mathrm{TRIS} / \mathrm{HCl}$ to allow specific detection of the M4T4 inhibitor.

\section{RESULTS}

\section{Inhibitor production by M4T4 group-A streptococci}

In a study of $450 \beta$-haemolytic streptococci (Tagg and Bannister, 1979), it was observed that only 13 strains produced one particular inhibitory pattern when tested against a set of nine standard indicator organisms. The 13 strains comprised 12 M4T4 group-A streptococci, and one group-C streptococcus. Among the group-A streptococcal strains, the production of this unique pattern $(++-+-++-+)$ seemed to be specifically related to the combination of $M$-antigen 4 with T-pattern 4 . Strains having other $M$ antigens $(22,24,26,29,46,48,56,60$ or 63$)$ with T-pattern 4 , and $M$-antigen 4 with T-pattern $8 / 25 / \mathrm{I}-19$, had different inhibitory spectra. All specific-inhibitor- 
negative derivatives of the M4T4 strains gave a different pattern of activity $(-----+--)$, indicating that the M4T4 strains were producing at least two inhibitors under the conditions of the test.

The inhibitory substance with activity directed solely against indicator I7 seems to be a non-type-specific substance produced by at least $85 \%$ of group-A streptococci (Tagg and Bannister, 1979). It does not seem to be produced in liquid media and is labile to heating at $80^{\circ} \mathrm{C}$ for $30 \mathrm{~min}$. Thus it seems unlikely to be present in active form in the specific-inhibitor preparations.

Studies of the inhibitory spectrum of the M4T4 inhibitor indicated that it was not active on gram-negative bacteria, although various gram-positive organisms besides streptococci were susceptible, including strains of Clostridium perfringens (welchii), Corynebacterium pseudodiphthericum, Bacillus

TABLE II

Results of screening tests for various streptococcal products and reactions*

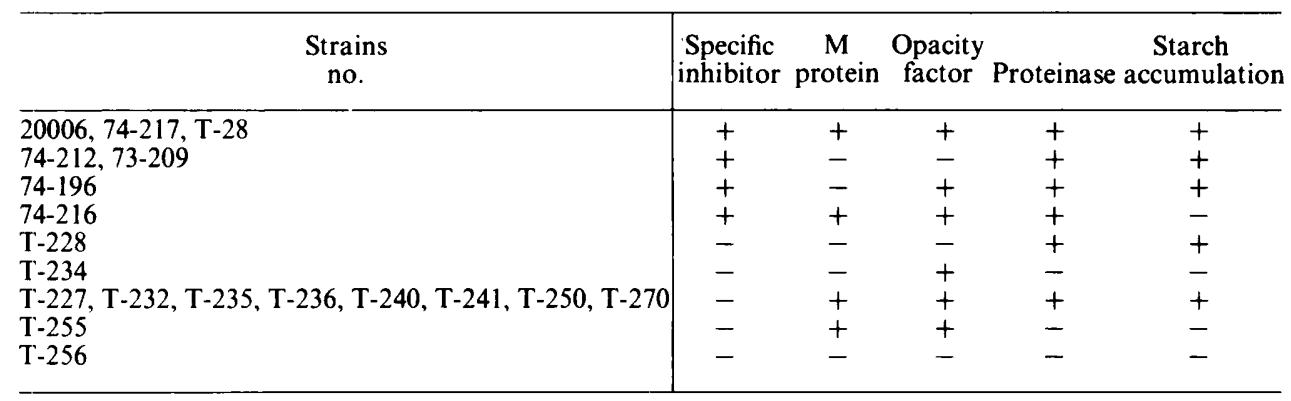

$+=$ Detected; $-=$ not detected

* All the strains formed amylase, DNAase and hyaluronidase, and were $\beta$ haemolytic.

megaterium and B. subtilis. Resistant bacteria included strains of Coryne. diphtheriae, Staph. aureus, Cl. histolyticum and B. cereus.

All inhibitor-positive M4T4 strains were immune to their homologous specific inhibitor and to each other's inhibitors when tested by the deferredantagonism method. Inhibitor-negative derivatives were sensitive to the inhibitor under these conditions.

It has been noted in the past that some M-type- 4 group-A streptococci are not sensitive to lysis by the virulent bacteriophage A25 (Malke, 1973). This observation presented the possibility that the inhibitor produced by M4T4 strains may be a defective phage A25. If so, inhibitor-negative derivatives of M4T4 strains should no longer be resistant to the phage. Accordingly, both inhibitor-positive and -negative M4T4 strains were tested for their susceptibility to plaquing by phage A25. None of the tested strains were sensitive to the bacteriophage.

Screening tests of various inhibitor-positive M4T4 strains and their inhibitor-negative derivatives indicated that production of the inhibitor occurred independently of the production of $\mathrm{M}$ protein, OF, amylase, DNAase, proteinase, hyaluronidase, starch or $\beta$-haemolysis. Representative results of the screening tests are shown in table II. 
In subsequent studies of the M4T4 inhibitor, strain 20006 was generally used as the prototype producer strain, strain T-250 as the inhibitor-negative derivative, and Staph. epidermidis strain T-18 as the indicator of the specific inhibitor.

\section{Conditions for inhibitor production}

The inhibitor was elaborated by the producer strains when tested by deferred antagonism on Columbia Blood Agar Base with or without the addition of human blood $8 \% \mathrm{v} / \mathrm{v}$. The agent was regularly produced at $25^{\circ} \mathrm{C}$ and $30^{\circ} \mathrm{C}$, but at $37^{\circ} \mathrm{C}$ its production was inconsistent from one test to another. Production on chocolate agar and on Todd-Hewitt agar was unreliable. Anaerobic incubation of blood-agar cultures appeared to increase production.

Inhibitor production in liquid media was best in Difco THB; THB supplemented with Neopeptone $1 \%(\mathrm{w} / \mathrm{v})$ gave less activity and was comparable with that obtained from TSB. Pfizer THB and Difco Brain Heart Infusion did not yield any detectable inhibitor. Difco THB supplemented with various additives was further tested for inhibitor production at different incubation temperatures. Optimal production after $18 \mathrm{~h}$ occurred at $25^{\circ} \mathrm{C}$ or $30^{\circ} \mathrm{C}$ in nutritionally unsupplemented THB (table III).

The effect of streptococcal proteinase on the yield of inhibitor was tested by mixing a heated, filtered culture supernate from strain 20006 (proteinase inactivated, inhibitor positive) and a filtered culture supernate of strain T250 (proteinase positive, inhibitor negative). After incubation at $37^{\circ} \mathrm{C}$ for $4 \mathrm{~h}$, there was no appreciable drop in the level of inhibitory activity. It was thus concluded that streptococcal proteinase did not inactivate the specific M4T4 inhibitor significantly. Production of the inhibitor did not appear to be inducible by either mitomycin $\mathrm{C}$ or ultraviolet irradiation. In fact, a reduced yield of inhibitor was generally observed after mitomycin-C treatment. This did not appear to be the result of reduced cell growth.

A study of the time-course of the production of the inhibitor indicated that it reached a detectable level when the producer-cell population entered the

TABLE III

Production of the inhibitor in Todd-Hewitt broth, and in this medium with various supplements

\begin{tabular}{l|rrr}
\hline $\begin{array}{c}\text { Supplement to } \\
\text { Todd-Hewitt broth }\end{array}$ & $\begin{array}{c}\text { Amount of inhibitor (in arbi- } \\
\text { trary units/mg dry weight of } \\
\text { cells) after } 18 \mathrm{~h} \text { at }\end{array}$ \\
\hline$\overbrace{25^{\circ} \mathrm{C}}$ & $30^{\circ} \mathrm{C}$ & $37^{\circ} \mathrm{C}$ \\
\hline None & 163 & 65 & 0 \\
Glucose $1 \%(\mathrm{w} / \mathrm{v})$ & 55 & 39 & 0 \\
Neopeptone $1 \%(\mathrm{w} / \mathrm{v})$ & 36 & 61 & 19 \\
Yeast extract $1 \%(\mathrm{w} / \mathrm{v})$ & 22 & 12 & 0 \\
$0 \cdot 5 \mathrm{M}$ TES buffer, $p \mathrm{H} 7 \cdot 0$ & 178 & 44 & $\ldots$ \\
\hline \multicolumn{4}{c}{$\ldots$ Not determined }
\end{tabular}


logarithmic growth phase, and that activity increased steadily with increasing cell numbers until the stationary growth phase had been reached. After incubation for $50 \mathrm{~h}$, inhibitor levels remained at the same initial peak level, although the cell count had fallen by two log units.

Relatively little activity was extractable from cell pellets (table IV). In general, culture supernates contained $c .8 \mathrm{AU} / \mathrm{ml}$, while up to $2 \mathrm{AU}$ were associated with the cell pellet. This gives a ratio of the maximum amount of activity extracted from the cell pellet to the activity present in the supernatant of $1: 200$.

TABLE IV

Attempts to extract cell-associated inhibitory activity from the cellular deposit of Todd-Hewittbroth culture

\begin{tabular}{lc}
\hline \multicolumn{1}{c}{ Extraction method } & $\begin{array}{c}\text { Arbitrary units (AU) } \\
\text { of cell-associated inhibitor } \\
\text { per 50 ml of 18-h culture* }\end{array}$ \\
\hline Saline $(p \mathrm{H} 2)$ & $1 \cdot 2$ \\
Saline $(p \mathrm{H} \mathrm{12)}$ & 0 \\
Saline $(p \mathrm{H} \mathrm{7)}$ & 0.5 \\
Mickle disintegration (15 min.) & 0.6 \\
Phage-associated lysin (40 units/ml) & 0 \\
7M urea & 0 \\
1M NaCl & 1.0 \\
Todd-Hewitt broth & $2 \cdot 0$ \\
\hline
\end{tabular}

* Supernate contained $c 8 \mathrm{AU} / \mathrm{ml}$.

\section{Purification of the inhibitor}

Some inhibitory activity was precipitated at $40-60 \%$ ammonium-sulphate saturation but the bulk of it precipitated at $60-80 \%$. Accordingly, a saturation level of $80 \%$ was routinely used to concentrate the inhibitor. The crude inhibitor preparation was then fractionated on Sephadex G-100 (table V). Extracts from strains 20006, 74-216 and T-250 gave similar spectrophotometric profiles. In the case of the inhibitor-positive strains 20006 and 74-216, it was found that the activity against Staph. epidermidis strain T-18 was contained within a single peak (figure). Fractions were also examined to locate $\mathrm{M}$ protein and OF; OF was eluted in the void volume but $\mathrm{M}$ protein not detected.

TABLE V

Summary of the stages of concentration and purification of the inhibitor

\begin{tabular}{l|rrrrrr}
\hline \multicolumn{1}{c|}{ Preparation } & $\begin{array}{c}\text { Volume } \\
(\mathrm{ml})\end{array}$ & $\begin{array}{c}\text { Inhibitor } \\
(\mathrm{AU} / \mathrm{ml})\end{array}$ & $\begin{array}{c}\text { Protein } \\
(\mathrm{mg} / \mathrm{ml})\end{array}$ & $\begin{array}{c}\text { Inhibitor } \\
\text { (AU/mg } \\
\text { of protein) }\end{array}$ & $\begin{array}{c}\text { Times } \\
\text { purified }\end{array}$ & $\begin{array}{c}\text { Percentage } \\
\text { recovery }\end{array}$ \\
\hline Culture supernate & 3000 & 8 & 12.2 & 0.65 & 1 & 100 \\
Crude inhibitor & 30 & 128 & 160 & 0.80 & 1.2 & 16 \\
Partially purified inhibitor & 150 & 4 & 4.3 & 0.93 & 1.4 & 2.5 \\
\hline
\end{tabular}

$\mathrm{AU}=$ arbitrary units. 


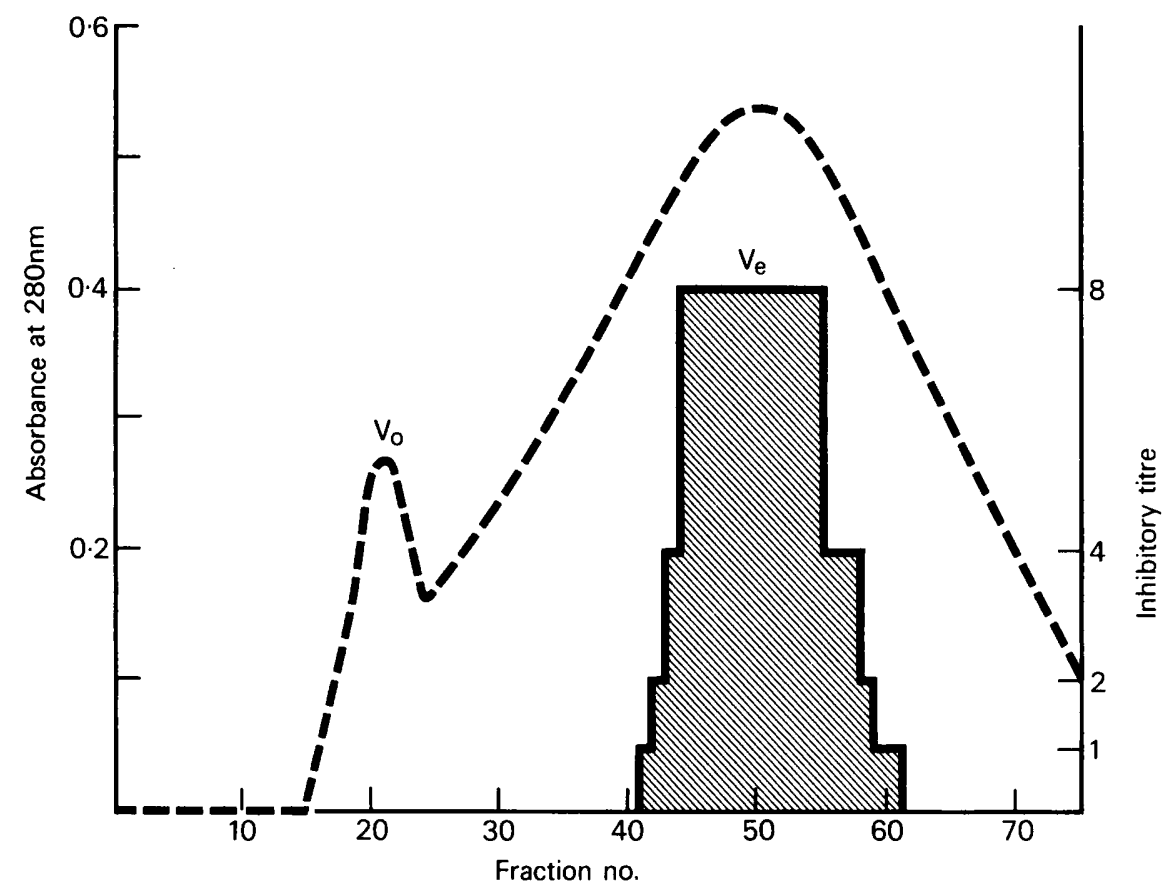

Figure. Absorbance at $280 \mathrm{~nm}$ (- - ) of the fractions eluted from Sephadex G-100, and inhibitory activity against Staphylococcus epidermidis strain T-18 $(\mathbb{N})$. The elution volume of the inhibitor $\left(\mathrm{V}_{\mathrm{e}}\right)$ divided by the void volume of the column $\left(V_{0}\right)$ gives a value of $2 \cdot 3$, which indicates a m.w. of 8-9000.

\section{Mode of action}

The inhibitor appeared to be adsorbed specifically to viable sensitive cells but not to heat-killed cells (table VI). A rapid reduction in the titre of the inhibitor was observed when it was added to Staph. epidermidis strain T-18. Another sensitive strain, 71-702, an M-type-32 streptococcus, was equally effective in adsorbing the inhibitor. The inhibitor was not adsorbed by viable or heat-killed cells of Escherichia coli, an organism not sensitive to the inhibitor. Adsorbed inhibitor could be recovered from washed Staph. epidermidis strain $\mathrm{T}-18$ cells by boiling in $\mathrm{NaCl} 0.85 \%$ (w/v) for $5 \mathrm{~min}$.

Repeated tests showed that the inhibitor had a bacteristatic effect on Staph. epidermidis strain $\mathrm{T}-18$, regardless of incubation temperature $\left(25^{\circ} \mathrm{C}, 30^{\circ} \mathrm{C}\right.$ or $37^{\circ} \mathrm{C}$ ) or of the amount of inhibitory activity added to the system within the range of final concentrations $3 \cdot 2-12 \cdot 8 \mathrm{AU} / \mathrm{ml}$. Similar tests were performed on strain PF-1643, and the action of the inhibitor was again bacteristatic.

The inhibitor was active against the producer strains when tested at high titre, although the sensitivity of these was low in comparison with that of Staph. epidermidis strain T-18. A preparation of titre 128 on Staph. epidermidis strain T-18 had a titre of 1 on the M4T4 producer strains, and titre of 4 on inhibitor-negative M4T4 derivatives.

The activity of the inhibitor appeared to be unaffected by treatment with type- $4 \mathrm{M}$ antiserum. A slight reduction in titre was observed when low-titre 
TABLE VI

Absorption of inhibitor to cells

\begin{tabular}{lc|c}
\hline \multicolumn{1}{c}{$\begin{array}{c}\text { Incubation of } \\
\text { inhibitor* } \\
\text { with }\end{array}$} & $\begin{array}{c}\text { Incubation } \\
\text { time (min.) }\end{array}$ & $\begin{array}{c}\text { Residual titre } \\
\text { of inhibitor }\end{array}$ \\
\hline Viable cells of & 0 & 4 \\
Staphylococcus & 1 & 2 \\
epidermidis strain & 5 & 1 \\
T-18 & 15 & 0 \\
Heat-killed cells of & 0 & 4 \\
Staph. epidermidis strain T-18 & 15 & 4 \\
Viable cells of & 0 & 4 \\
Escherichia coli & 15 & 4 \\
Heat-killed cells of & 0 & 4 \\
E. coli & 15 & 4 \\
\hline
\end{tabular}

* Initial titre 4 arbitrary units $(\mathrm{AU}) / \mathrm{ml}$.

$\dagger \mathrm{AU} / \mathrm{ml}$.

extracts were mixed with antiserum but not when mixed with pre-immune rabbit serum. However, this reduction in titre was apparent only when the levels of inhibitor were at the lower limits of detection. The results of these experiments are therefore inconclusive. It seems unlikely that the antiserum should have had any effect on the inhibitor, because the washed M4T4 cells used to stimulate production of the antiserum did not have any apparent inhibitory activity after preparation.

\section{Physicochemical properties}

The M4T4 inhibitor in crude and in partially purified states proved to be remarkably heat stable, being able to withstand autoclaving at $120^{\circ} \mathrm{C}$ for 90 min. without significant loss of activity. There was no appreciable loss of activity of either crude or partially purified inhibitor after storage at $4^{\circ} \mathrm{C}$ for 4 months. The inhibitor was stable in acid conditions but lost progressively more activity as the $p \mathrm{H}$ was increased beyond 7 (table VII).

TABLE VII

Effect of $p H^{*}$ on inhibitory activity

\begin{tabular}{cc}
\hline$p H$ & $\begin{array}{c}\text { Titre } \dagger \text { of inhibitor } \\
\text { after treatment }\end{array}$ \\
\hline $2-7$ & 64 \\
8 & 32 \\
9 & 16 \\
10 & 16 \\
11 & 8 \\
12 & 4
\end{tabular}

* Extracts were boiled for $15 \mathrm{~min}$. at the stated $p \mathrm{H}$ and readjusted to $p \mathrm{H}$ 6.5-7.0 before testing.

† Arbitrary units (AU)/ml; the initial titre was $64 \mathrm{AU} / \mathrm{ml}$. 
The crude inhibitor was sensitive to the action of proteolytic enzymes, showing a drop in titre from 4 to 1 after treatment with protease, and from 4 to 2 after trypsin treatment. It appeared to be more sensitive to proteolytic degradation in the partially purified than in the crude state, probably because of the removal of extraneous proteins that may have afforded some protective effect in the crude extract. The inhibitor was not sensitive to treatment with amylase, lipase or catalase.

The single peak of inhibitory activity on Sephadex G-100 had a $V_{e} / V_{o}$ value of 2.3 (strain 20006). This indicated that the inhibitor in the preparation was probably homogenous with respect to molecular size; comparison with the migration of standard proteins suggested a m.w. of $8-9000$. The m.w., as determined by polyacrylamide-gel electrophoresis and with reference to the same standard proteıns, was $c .9000$. The gels, when stained, revealed a diffuse protein band which corresponded to the position of a zone of inhibition in a similar gel embedded in agar and overlaid with a lawn of Staph. epidermidis strain T-18.

\section{Discussion}

In the present study it has been shown that M4T4 group-A streptococci produce a characteristic inhibitory substance that has many of the properties of the group of antibiotics commonly referred to as bacteriocines. Group-A streptococci of this serotype have previously been observed to have distinctive properties which tend to set them apart from other streptococci. They are said to be frequently associated with the development of acute glomerulonephritis (Stollerman, 1975) and scarlet fever (Lütticken et al., 1977) and also to produce large amounts of hyaluronidase (Gerlach \& Köhler, 1972), amylase (Crowley, 1950) and intracellular starch (Crowley, 1959). Recently, Köhler and Prokop (1978) were able to demonstrate a relationship between the haptoglobin genotype of human serum and its capacity to agglutinate group-A streptococci carrying the T4/24 antigen.

We attempted to determine the relationship, if any, between the production of the specific bacteriocine-like inhibitor by M4T4 group-A streptococci and the production of a variety of other streptococcal products. All the inhibitorpositive strains and their specific-inhibitor-negative derivatives produced amylase, hyaluronidase, DNAase, $\beta$-haemolysis and a non-type-specific inhibitory activity. Ageing of broth cultures of specific-inhibitor-positive strains gave rise to derivatives that were negative in varying combinations for the production of $\mathbf{M}$ protein, OF, proteinase and specific-inhibitor, and for starch accumulation. Loss of the inhibitor did not regularly appear to be associated with the loss of any of the other characteristics.

Production of the inhibitor described in this study seemed a characteristic of M4T4 strains of group-A streptococci, because none of the strains having other M antigens with T4 or other T antigens with M4 was found to produce this inhibitor. The unique nature of this relationship is so marked that we have been able to identify several isolates of group-A streptococci as presump- 
tive M4T4 strains on the basis of their inhibitory spectra and later have been able to confirm their identity serologically. A similar association has been found to exist between M-type 57 group-A streptococci and production of another bacteriocine-like inhibitor (Tagg and Bannister, 1979). The observation that one T-type-2 group-C streptococcal strain produces an inhibitory spectrum identical with that of the M4T4 strains is of interest and supports previous observations of the group-A-like properties of some group-C streptococci. Although it has been reported (Woolcock, 1974) that some group-C streptococci have M-like proteins, it was not possible to demonstrate the presence of type- $4 \mathrm{M}$ protein in the inhibitor-positive group-C streptococcus, and it formed the $\mathrm{T}$-antigen 2.

Bacteriophage action is unlikely to be responsible for the observed inhibition because the inhibitory substance was freely diffusable through agar up to $5 \mathrm{~mm}$ in thickness. A defective form of phage A25, or alternatively, a prophage such as P5004 (Malke, 1973), did not seem to have any relationship to the inhibitor, because inhibitor-negative derivatives of M4T4 strains did not support the propagation of phage A25. The reasons for believing that the inhibitory activity of M4T4 strains, and many other streptococci, cannot be accounted for by hydrogen-peroxide production, change of $p \mathrm{H}$ or exhaustion of essential nutrients have been set out elsewhere (Tagg and Bannister, 1979).

Many of the properties of the M4T4 inhibitor are similar to those observed for other bacteriocines, in particular, streptococcin A-FF22 (table VIII), from which, however, it differs in several respects.

The inhibitor showed no activity against its own producer strain when tested by deferred antagonism. However, some "auto-inhibitory" activity was observed when high-titre extracts were tested, indicating that the immunity was not complete. Immunity breakdown in bacteria exposed to high concentrations of homologous bacteriocine is commonly observed in grampositive species including streptococci (Tagg et al., 1973b; Tagg, Dajani and Wannamaker, 1975). However, inhibitor-negative derivatives of the M4T4 strains were more sensitive to the specific inhibitor than the parent strain; this suggests a possible plasmid-type linkage between the genes for production and those for immunity similar to that reported for streptococcin A-FF22 (Tagg and Wannamaker, 1976).

Sherwood et al. (1954), Diebel (1963) and Liu et al. (1963) have shown that production of streptococcal proteinase is favoured under anaerobic conditions. It was surprising, therefore, to observe that anaerobic incubation of specific-inhibitor-producing strains on blood agar gave rise to an apparent increase in activity of the inhibitor. Elliott (1945) showed that production of streptococcal proteinase is enhanced at elevated temperatures, especially in the presence of yeast extract $1 \%(\mathrm{w} / \mathrm{v})$, but is reduced at lower temperatures and in the presence of Neopeptone $1 \%(\mathrm{w} / \mathrm{v})$. In the present study, a decreased yield of inhibitor was observed at higher temperatures and in the presence of yeast extract. However, there appeared to be no correlation between the presence or absence of Neopeptone and the production of the inhibitor, since the yield was reduced in the presence of Neopeptone. This suggested that the inhibitor 
TABLE VIII

Comparison of the properties of the specific M4T4 inhibitor and streptococcin A-FF22

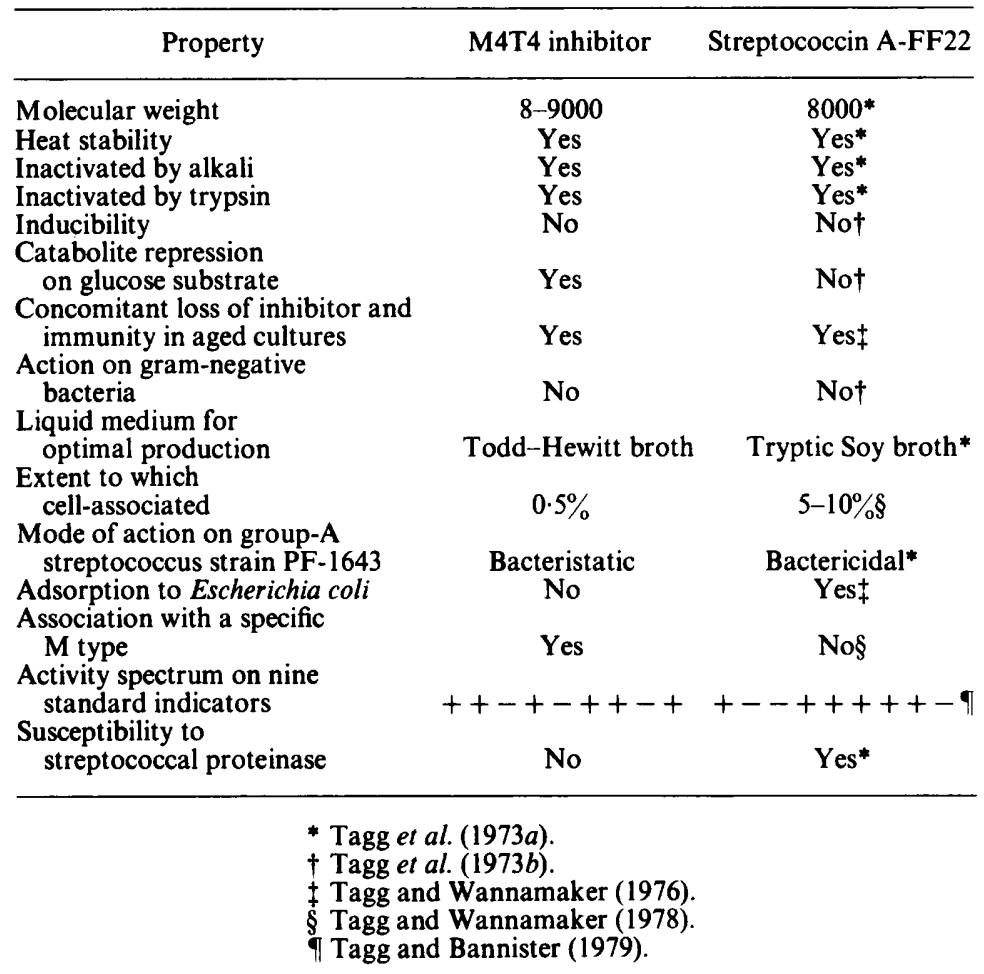

was not sensitive to the proteinase elaborated by M4T4 streptococci and this was further supported by the fact that inhibitor levels in broth cultures rose as a direct proportion to cell numbers, and when maximum titre had been reached did not decrease with time. These observations are in direct contrast to the apparent effects of streptococcal proteinase on streptococcin A-FF22 (Tagg et al., 1973a).

There appeared to be some catabolite repression of specific inhibitor production when glucose was fermented, an effect observed to influence the production of several other bacteriocines (Horák, 1973; Lavoie, Mathieu and Charron-Allie, 1974; Tagg, Dajani and Wannamaker, 1975). Production of the inhibitor was not inducible by treatment with either mitomycin $\mathrm{C}$ or irradiation with ultraviolet light. These results were not unexpected because it has been found that such treatment is not always effective and in some cases, as in the present study, can lead to a decreased yield of bacteriocine (Tagg, Dajani and Wannamaker, 1976a). In contrast to streptococcin A-FF22 (Tagg and Wannamaker, 1978), the M4T4 inhibitor was not markedly cell-associated, and was thus unlikely to be an integral part of the cell wall or to be adsorbed non-specifically to the cell envelope.

It is highly unlikely that the M4T4 inhibitor is related to any of the known streptococcal enzymes, since the extracts had undergone prolonged heating 
before testing. Proteinase, hyaluronidase, and haemolytic activity could not detected in the extracts. Ammonium-sulphate-treated extracts contained OF and trace amounts of $M$ protein, but after fractionation on Sephadex G-100 both were absent from the inhibitor-positive fractions. This was to be expected in view of the relatively high m.w. of these proteins in comparison with that of the inhibitor. The M4T4 inhibitor seemed to bind only to viable, inhibitorsensitive bacteria; this seemed to suggest that it might undergo enzymatic degradation. However, this did not appear to be the case, because bound inhibitor could be recovered from the treated cells by boiling in $0.85 \%(\mathrm{w} / \mathrm{v})$ $\mathrm{NaCl}$ after they had been washed several times in saline.

A bacteriocine-like substance with bacteristatic rather than bactericidal action is most unusual, but this has been reported for staphyloccin 462 by Hale and Hinsdill (1975). Also, Dajani, Tom and Law (1976) have described a viridin with bactericidal action on some sensitive strains and bacteristatic action on others.

\section{SUMMARY}

A unique and characteristic bacteriocine-like inhibitor elaborated by M-type 4, T-pattern 4, group-A streptococci was isolated and partially purified. This inhibitor was found to be produced optimally in Todd-Hewitt broth; after extraction and concentration, was shown to be protein in nature, and to have a m.w. of $c .8000$. It was extremely heat stable and acid tolerant, but was quickly inactivated in alkaline conditions. It could be demonstrated in cell-bound form, but $99.5 \%$ was found in culture supernates. It was specifically adsorbed by viable sensitive cells, and its mode of action was bacteristatic.

This work was supported by grants from the Medical Research Council of New Zealand and from the US Public Health Service (AI 08724). J.R.T. was supported for part of this study by a Minnesota Heart Association Fellowship. L.W.W. is a Career Investigator of the American Heart Association.

\section{REFERENCES}

Cleary, P. P., Johnson, Z. and Wannamaker, L. W. 1975. Genetic instability of M protein and serum opacity factor of group A streptococci: evidence suggesting extrachromosomal control. Infect. Immun., 12, 109.

Crowley, N. 1950. The degradation of starch by strains of group A streptococci having related antigens. J.gen. Microbiol., 4, 156.

CROWLEY, N. 1959. The association of starch-accumulating strains of group A streptococci with acute nephritis and acute rheumatic fever. J. Hyg., Camb., 57, 235.

Dajani, A. S., Tom, M. C. AND LAW, D. J. 1976. Viridins, bacteriocins of alpha-hemolytic streptococci: isolation, characterisation and partial purification. Antimicrob. Agents Chemother., 9, 81 .

Dajani, A. S. AND Wannamaker, L. W. 1969. Demonstration of a bactericidal substance against beta-hemolytic streptococci in supernatant fluids of staphylococcal cultures. $J$. Bact., $97,985$.

Dajani, A. S. AND Wannamaker, L. W. 1973. Kinetic studies on the interaction of bacteriophage type 71 staphylococcal bacteriocin with susceptible bacteria. J. Bact., 114, 738.

DEIBEL, R. H. 1963. Hydrolysis of proteins and nucleic acids by Lancefield group A and other streptococci. J. Bact., 86, 1270. 
Elliotr, S. D. 1945. A proteolytic enzyme produced by group A streptococci with special referel.ze to its effect on the type-specific $M$ antigen. J. exp. Med., 81, 573.

GERLACH, D. AND KöHLER, W. 1972. Hyaluronate lyase from Streptococcus pyogenes. I. The production and isolation of hyaluronate lyase. Zentbl. Bakt. ParasitKde, I. Abt. Orig., A221, 166 (in German).

HALE, E. M. AND HinSDILl, R. D. 1975. Biological activity of staphylococcin 462: bacteriocin from Staphylococcus aureus. Antimicrob. Agents Chemother., 7, 74.

Horák, V. 1973. Glucose repression of the synthesis of some colicins. Folia Microbiol., Praha, $18,75$.

Jetten, A. M., Vogels, G. D. AND DE Windt, F. 1972. Production and purification of a Staphylococcus epidermidis bacteriocin. J. Bact., 112, 235.

KöHLER, W. AND Prokop, O. 1978. Relationship between haptoglobin and Streptococcus pyogenes T4 antigens. Nature, Lond., 271, 373.

LAEMMLI, U.K. 1970. Cleavage of structural proteins during the assembly of the head of bacteriophage T4. Nature, Lond., 227, 680.

Lavoie, M., Mathieu, L. G. and Charron-Allie, L. 1974. Inhibition of colicin production by fermentable sugars. Can. J. Microbiol., 20, 269.

LEE, WIE-ShING. 1976. Use of Mueller-Hinton agar as amylase testing medium. J. clin. Microbiol., 4, 312.

Liu, T.-Y., Neumann, N. P., Elliott, S. D., Moore, S. and Stein, W. H. 1963. Chemical properties of streptococcal proteinase and its zymogen. J. biol. Chem., 238, 251.

Lowry, O. H., Rosenbrough, N. J., Farr, A. L. and Randall, R. L. 1951. Protein measurement with the Folin phenol reagent. J. biol. Chem., 193, 265.

LÜTTICKEN, R., WeNDORFF, U., LÜTTICKEN, D. AND WaNNAMAKER, L. W. 1977. Typing of group A streptococci from an urban area (Köln) in West Germany. Zentbl. Bakt. ParasitKde, I Abt. Orig., A237, 35.

MalKe, H. 1973. Phage A25-mediated transfer induction of a prophage in Streptococcus pyogenes. Molec. gen. Genet., 125, 251.

MaXted, W. R., Widdowson, J. P., Fraser, C. A. M., Ball, L. C. and Bassett, D. C. J. 1973. The use of the serum opacity reaction in the typing of group-A streptococci. J. med. Microbiol., 6, 83.

Mayr-Harting, A., Hedges, A. J. and Berkeley, R. C. W. 1972. Methods for studying bacteriocins. In Methods in microbiology, edited by J. R. Norris and D. W. Ribbons, New York and London, vol. 7A, p. 327.

MurRay, R. G. E. AND PEARCE, R. H. 1949. The detection and assay of hyaluronidase by means of mucoid streptococci. Can. J. Res., 27E, 254.

Ouchterlony, O. 1949. Antigen-antibody reaction in gels. Acta path. microbiol. scand., 26, 507.

Sherwood, N. P., Paretsky, D., Nachtigall, A., Mclain, A. R. and Truffelli, G. T. 1954. Studies on streptococci. V. A study of streptococcal proteinases. J. infect. Dis., 95, 1.

Stollerman, G. H. 1975. The relative rheumatogenicity of strains of group A streptococci. Mod. Con. cardiovasc. Dis., 44, 35.

TAGG, J. R. AND BANNISTER, V. 1979. "Fingerprinting" $\beta$-haemolytic streptococci by their production of and sensitivity to bacteriocine-like inhibitors. J. med. Microbiol. 12, 397.

TAGG, J. R., DAJANi, A. S. AND WANNAMAKER, L. W. 1975. Bacteriocin of a group B streptococcus: partial purification and characterisation. Antimicrob. Agents Chemother., 7,764 .

TAGg, J. R., Dajani, A. S. And Wannamaker, L. W. 1976a. Bacteriocins of gram-positive bacteria. Bact. Rev., 40.722.

TAGG, J. R., Dajani, A. S., Wannamaker, L. W. and Gray, E. D. 1973a. Group A streptococcal bacteriocin. Production, purification and mode of action. J. exp. Med., 138, 1168.

TAGG, J. R. AND MCGIVEN, A. R. 1971. Assay system for bacteriocins. Appl. Microbiol., 21, 943.

TAGG, J. R., READ, R. S. D. AND MCGiven, A. R. 1973b. Bacteriocin of a group A streptococcus: partial purification and properties. Antimicrob. Agents Chemother., 4, 214. 
TAGG, J. R., SkJold, S. and Wannamaker, L. W. 1976B. Transduction of bacteriocin determinants in group A streptococci. J. exp. Med., 143, 1540.

TAGG, J. R. AND WanNamakeR, L. W. 1976. Genetic basis of streptococcin A-FF22 production. Antimicrob. Agents Chemother., 10, 299.

TAGG, J. R. AND WANNAMAKER, L. W. 1978. Streptococcin A-FF22: nisin-like antibiotic substance produced by a group A streptococcus. Antimicrob. Agents Chemother., 14, 31 .

WoOLCOCK, J. B. 1974. Purification and antigenicity of an M-like protein of Streptococcus equi. Infect. Immun., 10, 116. 